\title{
О.Е. Пошехонова
}

ФИЦ Тюменский научный центр СО РАН ул. Малыгина, 86, Тюмень, 625026 E-mail: poshehonova.olg@gmail.com

\section{НОВЫЕ ДАННЫЕ ПО КРАНИОЛОГИИ ВЕРХНЕТАЗОВСКИХ СЕЛЬКУПОВ}

Отмечено, что антропологическое своеобразие отдельных групп коренного населения Западной Сибири сфрормировалось в результате поздних метисационных процессов, произошедших в новое время. Судя по историческим и этнолингвистическим данным, одним из таких народов являются северные селькупы, переселившиеся в XVII-XVIII вв. из Нарымского Приобья в верховья р. Таз по политическим, экономическим и, возможно, экологическим причинам. Важным источником для реконструкции процесса формирования данной группы могут быть палеоантропологические данные. В статье вводится в научный оборот и анализируется краниологическая серия из могильника Кикки-Акки, полученная в 2013 г. и пополненная в 2016 г. Дана морфологическая характеристика серии, выполнены анализ внутригрупповой изменчивости и сопоставление полученных данных с выборками близкого к современности времени из Западной Сибири. Установлено, что нарымские селькупы действительно являются предками верхнетазовских селькупов, но в результате миграции на север, за небольшой промежуток времени, их фризический облик довольно сильно изменился. Формирование антропологического своеобразия верхнетазовских селькупов протекало при активной метисации двух компонентов, относящихся к одной западно-сибирской формации. Первый из них связан в генезисе с восточными хантами, второй с нарымскими селькупами. Однако, судя по всему, к XVIII-XIX вв. биологические связи северных селькупов с предковой южной группой сильно ослабли и угорский компонент становится доминирующим.

Ключевые слова: Западная Сибирь, позднее средневековье, северные селькупы, палеоантропология, антропологический тип, краниология.

DOI: 10.20874/2071-0437-2018-41-2-109-118

Работа выполнена по госзаданию согласно Плану НИР ТюмНЦ СО РАН на 2018-2020 г2., протокол № 2 от 08.12.2017 2. Приоритетное направление XII.186.; Программа XII.186.4; проект № 0371-2018-0034.

\section{Введение}

Благодаря усилиям нескольких поколений ученых краниология коренного населения Западной Сибири изучена достаточно подробно, проведена масштабная антропологическая классификация отдельных популяций и групп популяций [Дебец, 1951; Гохман, 1982; Дремов, 1998а, 1998b; Дремов, Багашев, 1998; Багашев, 1998, 2001, 2002; Ким, 1998]. В результате этого удалось выделить и обосновать существование древнего вторичного западно-сибирского очага расообразования с тремя дочерними третичными [Багашев, 2017]. Однако отмечено, что антропологическое своеобразие отдельных групп сформировалось в результате поздних метисационных процессов, происходивших в Западной Сибири в новое время [Там же, с. 352]. Судя по историческим и этнолингвистическим данным, одним из таких народов являются северные селькупы. Ареал расселения верхнетазовских селькупов сейчас находится в верховьях Таза и простирается от р. Ратта до р. Толька. Считается, что это потомки нарымских селькупов, мигрировавших по политическим, экономическим и, возможно, экологическим причинам в XVII-XVIII вв. из Нарымского Приобья на север, через территорию бассейна р. Вах [Пелих, 1981, с. 8-74]. Важным источником для решения вопроса их происхождения могут быть палеоантропологические данные.

Недавно появились первые антропологические и археологические данные по северной группе селькупов вообще и по верхнетазовским селькупам в частности [Пошехонова, 2015b]. Изучение морфологических особенностей этой небольшой выборки позволило предварительно охарактеризовать антропологический тип северных селькупов [Пошехонова, 2015а]. Было сделано предположение об их близости в разной степени к восточным хантам и нарымским сель- 


\section{О.Е. Пошехонова}

купам. В настоящее время краниологическая коллекция по верхнетазовским селькупам существенно пополнилась, что вызвало необходимость более тщательного анализа.

Цель данного исследования - выявление антропологического своеобразия и происхождения верхнетазовских селькупов, определение их положения в системе антропологических типов Западной Сибири. Задачи - введение в научный оборот новых материалов, анализ внутригрупповой изменчивости для выделения краниологических компонентов их структуры, участвовавших в генезисе популяции, и сопоставление полученных данных с выборками близкого к современности времени из Западной Сибири.

\section{Материалы}

Часть материала получена в 2013 г. в ходе раскопок могильника Кикки-Акки (Красноселькупский район ЯНАО, р. Таз, устье р. Коралькы), тогда было вскрыто шесть погребений. Небольшая коллекция черепов (3 мужских, 3 женских) была изучена по стандартной краниологической программе, сделаны предварительные выводы [Пошехонова, 2015b]. Работы на памятнике были продолжены в 2016 г., исследовано еще 12 могил. Таким образом, краниологическая серия из могильника Кикки-Акки насчитывает 21 череп - 13 мужских и 8 женских. Сохранность материалов очень хорошая. По уточненным данным могильник датируется XVIII-XIX вB., культурная и этническая принадлежность - северные (верхнетазовские) селькупы.

\section{Методы}

Краниологическое исследование проводилось по стандартной методике Р. Мартина в модификации В.П. Алексеева и Г.Ф. Дебеца [1964]. Дополнительно вычислялся угол поперечного изгиба лба [Гохман, 1961] и применялись несколько индексов: указатель уплощенности лицевого скелета (УЛС), преаурикулярный фацио-церебральный указатель (ПФЦ), условная доля монголоидного элемента (УДМЭ) [Дебец, 1968], модули профилированности переносья (МПП) и лица (МПЛ) [Гохман, 1980]. Внутригрупповая изменчивость исследовалась с применением кластерного анализа на основании эвклидовых расстояний, межгрупповая - с помощью канонического анализа.

\section{Результаты}

В среднем мужские и женские черепа с учетом полового диморфизма не отличаются по своим морфологическим характеристикам, данную группу можно описать следующим образом (табл. 1, 2). Низкие субдолихокранные черепа имеют средние продольные и поперечные диаметры. По высотно-продольному указателю они ортокранные, по высотно-поперечному - метриокранные. Лоб узкий, весьма наклонный, в горизонтальной плоскости профилирован средне. Мезопрозопное лицо среднеширокое на всех уровнях, по высоте попадает в среднюю группу, скуловой диаметр также характеризуется средней величиной. Горизонтальная профилировка лицевого скелета мужских черепов на верхнем уровне на границе средних и больших показателей, в подносовой части она гораздо сильнее. Лица женских черепов на уровне орбит уплощены, а на зигомаксиллярном - профилированы. В вертикальной плоскости по всем показателям лицо ортогнатное, в альвеолярной части - мезогнатное. Мезоконхные по пропорциям орбиты характеризуются средней высотой, ширина орбиты женских черепов большая, мужских - средняя. Нос средней ширины и высоты, мезоринный. Переносье уплощено, по абсолютным показателям низкое и узкое, на дакриальном уровне относительно более широкое. Угол выступания носовых костей очень малый. Нижняя челюсть характеризуется средними размерами практически по всем показателям. Краниологическое своеобразие данной группы сводится к сочетанию следующих признаков: низкий субдолихокранный череп, незначительно уплощенное среднеширокое и средневысокое мезопрозопное лицо, плоское переносье и очень малый угол выступания носа.

Судя по отмеченным морфологическим особенностям, группа занимает промежуточное положение между европеоидными и монголоидными вариантами с тяготением к последним. При этом по уплощенности лицевого скелета (УЛС) серия приближается к классическим монголоидным выборкам, а по особенностям строения мозговой капсулы - к европеоидным. В результате условная доля монголоидного элемента составила 76,8 и 76,5 \%.

По ряду признаков были зафиксированы значительные величины статистических отклонений, что может служить указанием на неоднородность антропологического состава изучаемой палеопопуляции. В связи с этим был проведен анализ внутригрупповой изменчивости мужской части серии; малочисленность женских черепов не позволила выполнить такое исследование. 


\section{Размеры и указатели мужских черепов из могильника Кикки-Акки}

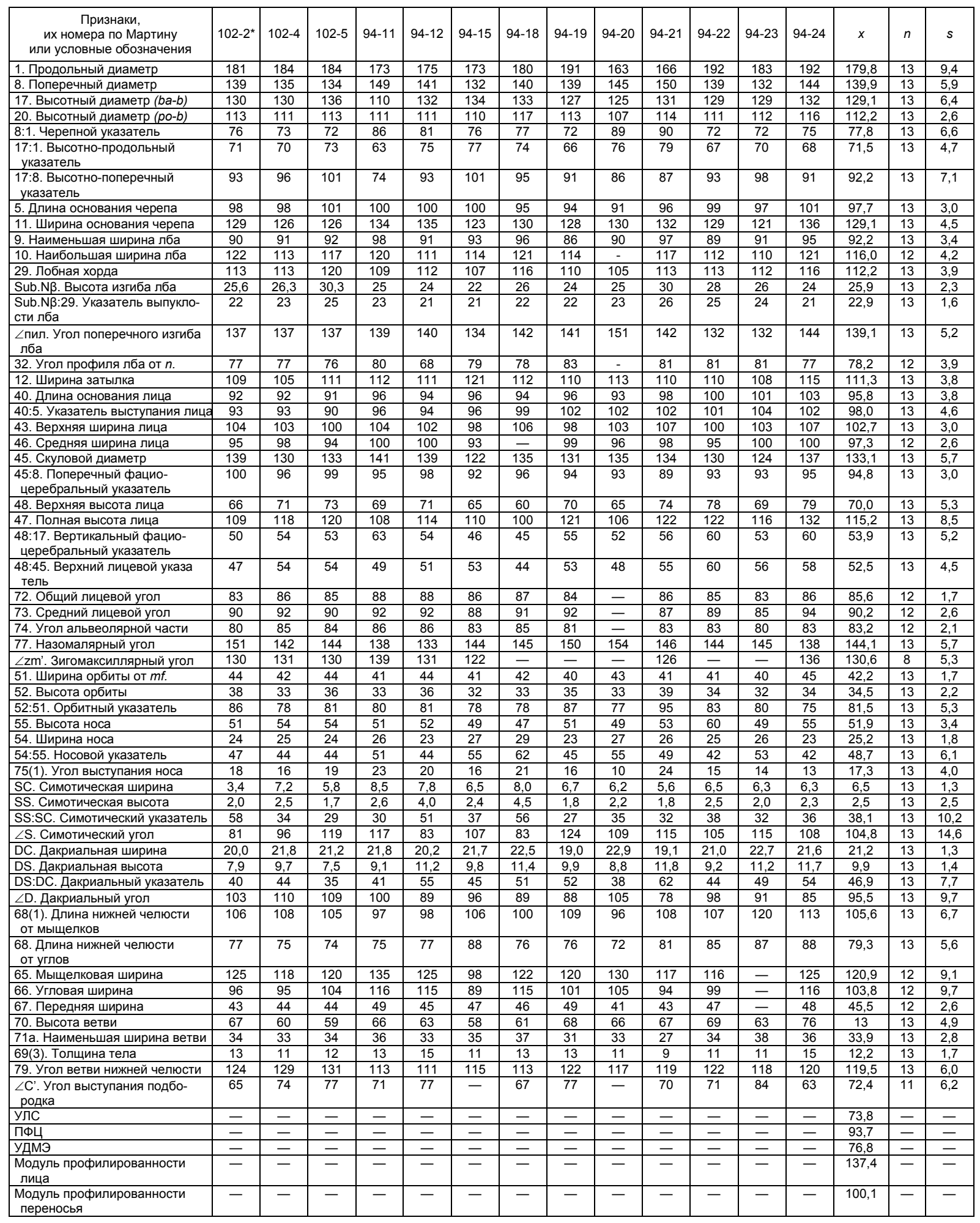

* Инвентарный номер. 


\section{Размеры и указатели женских черепов из могильника Кикки-Акки}

\begin{tabular}{|c|c|c|c|c|c|c|c|c|c|c|c|}
\hline $\begin{array}{c}\text { Признаки, их номера по Мартину } \\
\text { или условные обозначения }\end{array}$ & $102-3^{*}$ & $102-6$ & $102-8$ & $94-14$ & $94-17$ & $94-26$ & $94-27$ & $94-28$ & $x$ & $n$ & $s$ \\
\hline 1. Продольный диаметр & 185 & 173 & 172 & 160 & 171 & 174 & 175 & 173 & 172,9 & 8 & 6,8 \\
\hline 8. Поперечный диаметр & 135 & 132 & 140 & 134 & 135 & 126 & 131 & 141 & 134,2 & 8 & 4,8 \\
\hline 17. Высотный диаметр (ba-b) & 126 & 120 & 124 & 135 & 121 & 121 & 125 & 135 & 125,9 & 8 & 6,0 \\
\hline 20. Высотный диаметр (po-b) & 108 & - & 109 & - & 104 & 103 & 106 & 115 & 107,5 & 6 & 4,3 \\
\hline 8:1. Черепной указатель & 72 & 76 & 81 & 84 & 79 & 72 & 74 & 81 & 77,4 & 8 & 4,5 \\
\hline 17:1. Высотно-продольный указатель & 68 & 69 & 72 & 84 & 71 & 69 & 71 & 78 & 72,8 & 8 & 5,5 \\
\hline 17:8. Высотно-поперечный указатель & 93 & 90 & 88 & 100 & 90 & 96 & 95 & 95 & 95,4 & 8 & 4,1 \\
\hline 5. Длина основания черепа & 100 & 92 & 97 & 96 & 93 & 96 & 94 & 95 & 95,4 & 8 & 2,5 \\
\hline 11. Ширина основания черепа & 123 & 123 & 121 & 112 & 119 & 116 & 123 & 128 & 120,6 & 8 & 4,9 \\
\hline 9. Наименьшая ширина лба & 96 & 87 & - & 90 & 91 & 87 & 85 & 89 & 89,3 & 7 & 3,6 \\
\hline 10. Наибольшая ширина лба & 115 & - & - & - & 111 & 102 & 108 & 115 & 110,2 & 5 & 5,4 \\
\hline 29. Лобная хорда & 110 & - & 105 & 108 & 111 & 103 & 104 & 110 & 107,3 & 7 & 3,2 \\
\hline Sub.Nß. Высота изгиба лба & 25,4 & - & 26,2 & 24 & 25 & 25 & 24 & 25 & 25,0 & 7 & 0,7 \\
\hline Sub.Nß:29. Указатель выпуклости лба & 23 & - & 24 & 22 & 22 & 24 & 23 & 22 & 22,9 & 7 & 0,9 \\
\hline Спил. Угол поперечного изгиба лба & 137,0 & 142 & - & 143 & 142 & 135 & 140 & 143 & 140,3 & 7 & 3,1 \\
\hline 32. Угол профиля лба от $n$. & 79 & - & - & - & 75 & 78 & 81 & 85 & 79,6 & 5 & 3,7 \\
\hline 12. Ширина затылка & 105 & 108 & 104 & - & 111 & 106 & 108 & 113 & 107,9 & 7 & 3,2 \\
\hline 40. Длина основания лица & 98 & 90 & 97 & - & 88 & 96 & 95 & 86 & 92,8 & 7 & 4,7 \\
\hline 40:5. Указатель выступания лица & 98 & 97 & 100 & - & 94 & 100 & 101 & 90 & 97,1 & 7 & 3,9 \\
\hline 43. Верхняя ширина лица & 106 & 98 & - & 101 & 97 & 99 & 100 & 100 & 100,1 & 7 & 2,9 \\
\hline 46. Средняя ширина лица & 104 & 93 & - & - & 91 & 92 & 98 & 94 & 95,3 & 6 & 7,9 \\
\hline 45. Скуловой диаметр & 127 & 124 & 126 & - & 124 & 122 & 121 & 126 & 124,3 & 7 & 2,2 \\
\hline 45:8. Поперечный фацио-церебральный указатель & 94 & 93 & 90 & - & 92 & 96 & 92 & 89 & 92,3 & 7 & 2,4 \\
\hline 48. Верхняя высота лица & 69 & 65 & 63 & 61 & 64 & 60 & 69 & 71 & 65,2 & 8 & 4,0 \\
\hline 47. Полная высота лица & 107 & 106 & 103 & - & 107 & 100 & 116 & 113 & 107,4 & 7 & 5,5 \\
\hline $\begin{array}{l}\text { 48:17. Вертикальный фацио-церебральный указа- } \\
\text { тель }\end{array}$ & 54 & 58 & 50 & 48 & 53 & 49 & 55 & 52 & 52,4 & 8 & 3,3 \\
\hline 48:45. Верхний лицевой указатель & 54 & 52 & 50 & - & 52 & 49 & 57 & 56 & 52,9 & 7 & 3,0 \\
\hline 72. Общий лицевой угол & 85 & - & - & - & 86 & 77 & 84 & 89 & 84,2 & 5 & 4,4 \\
\hline 73. Средний лицевой угол & 91 & - & - & - & 90 & 84 & 88 & 91 & 88,8 & 5 & 3,0 \\
\hline 74. Угол альвеолярной части & 84 & - & - & - & 84 & 74 & 82 & 86 & 82,0 & 5 & 4,7 \\
\hline 77. Назомалярный угол & 140 & 144 & - & 152 & 145 & 150 & 145 & 142 & 145,4 & 7 & 4,2 \\
\hline$\angle \mathrm{zm}$. Зигомаксиллярный угол & 129 & 126 & - & - & 131 & 133 & 129 & - & 129,6 & 5 & 2,6 \\
\hline 51. Ширина орбиты от mf. & 44 & 43 & 44 & - & 40 & 42 & 42 & 42 & 42,4 & 7 & 1,4 \\
\hline 52. Высота орбиты & 36 & 34 & 33 & - & 36 & 35 & 33 & 35 & 34,6 & 7 & 1,3 \\
\hline 52:51. Орбитный указатель & 81 & 79 & 75 & - & 90 & 83 & 78 & 83 & 81,3 & 7 & 4,8 \\
\hline 55. Высота носа & 50 & 47 & 46 & 45 & 48 & 44 & 48 & 53 & 47,6 & 8 & 2,9 \\
\hline 54. Ширина носа & 28 & 24 & - & 22 & 23 & 23 & 23 & 25 & 24,0 & 7 & 2,0 \\
\hline 54:55. Носовой указатель & 56 & 51 & - & 48 & 48 & 52 & 48 & 47 & 50,0 & 7 & 3,2 \\
\hline 75(1). Угол выступания носа & 11 & 9 & - & - & 12 & 11 & 20 & 13 & 12,7 & 6 & 3,8 \\
\hline SC. Симотическая ширина & 6,3 & 7,0 & - & 8,3 & 7,5 & 5,2 & 5,7 & 4,5 & 6,4 & 7 & 1,3 \\
\hline SS. Симотическая высота & 2,3 & 1,8 & - & 2,8 & 1,2 & 2,2 & 2,5 & 1,7 & 2,1 & 7 & 0,5 \\
\hline SS:SC. Симотический указатель & 36 & 25 & - & 34 & 16 & 42 & 43 & 37 & 33,3 & 7 & 9,7 \\
\hline$\angle \mathrm{S}$. Симотический угол & 108 & 126 & - & 111 & 145 & 100 & 97 & 106 & 113,3 & 7 & 16,8 \\
\hline DC. Дакриальная ширина & 19,5 & 20,7 & - & 19,8 & 21,8 & 19,2 & 19,7 & 21,1 & 20,2 & 7 & 1,0 \\
\hline DS. Дакриальная высота & 9,8 & 5,8 & - & 9,0 & 6,2 & 8,0 & 8,4 & 7,3 & 7,8 & 7 & 1,4 \\
\hline DS:DC. Дакриальный указатель & 50 & 28 & - & 45 & 28 & 42 & 42 & 34 & 38,4 & 7 & 8,6 \\
\hline$\angle \mathrm{D}$. Дакриальный угол & 90 & 121 & - & 95 & 121 & 100 & 99 & 111 & 105,3 & 7 & 12,5 \\
\hline 68(1). Длина нижней челюсти от мыщелков & 一 & 98 & 104 & 108 & 94 & 98 & 103 & 97 & 100,3 & 7 & 4,9 \\
\hline 68. Длина нижней челюсти от углов & 62 & 69 & 80 & 77 & 69 & 72 & 73 & 71 & 71,6 & 8 & 5,4 \\
\hline 65. Мыщелковая ширина & - & 113 & 112 & 119 & 110 & 115 & 110 & 120 & 114,1 & 7 & 4,1 \\
\hline 66. Угловая ширина & 93 & 96 & 95 & 97 & 92 & 91 & 89 & 100 & 94,1 & 8 & 3,6 \\
\hline 67. Передняя ширина & 42 & 43 & 43 & 41 & 36 & 44 & 47 & 44 & 42,5 & 8 & 3,2 \\
\hline 70. Высота ветви & 61 & 51 & 55 & 59 & 49 & 49 & 64 & 61 & 56,1 & 8 & 5,9 \\
\hline 71а. Наименьшая ширина ветви & - & 34 & 35 & 34 & 30 & 33 & 35 & 30 & 33,0 & 7 & 2,2 \\
\hline 69(3). Толщина тела & 10 & 11 & 12 & 14 & 11 & 12 & 12 & 11 & 11,6 & 8 & 1,3 \\
\hline 79. Угол ветви нижней челюсти & 133 & 129 & 122 & 122 & 126 & 131 & 123 & 126 & 126,5 & 8 & 4,2 \\
\hline$\angle \mathrm{C}^{\prime}$. Угол выступания подбородка & 72 & 72 & 61 & - & 86 & 76 & 75 & 68 & 72,9 & 7 & 7,7 \\
\hline УЛС & - & - & - & - & - & - & - & - & 79,1 & - & - \\
\hline ПФЦ & - & - & - & - & - & - & - & - & 92,5 & - & - \\
\hline УДМЭ & - & - & - & - & - & - & - & - & 76,5 & - & - \\
\hline Модуль профилированности лица & - & - & - & - & - & - & - & - & 137,5 & - & - \\
\hline Модуль профилированности переносья & - & - & - & - & - & - & - & - & 109,3 & - & - \\
\hline
\end{tabular}

* Инвентарный номер. 


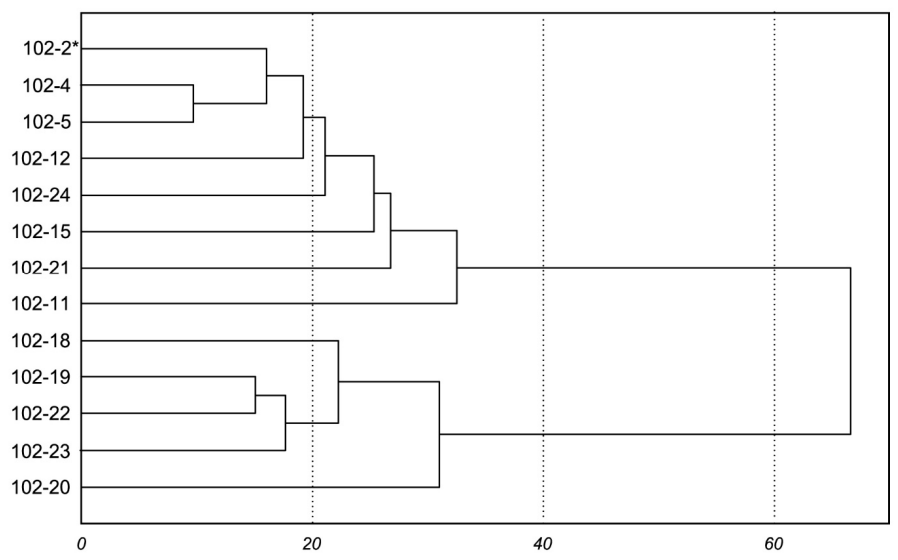

Рис. 1. Кластеризация мужских черепов из могильника Кикки-Акки ( ${ }^{*}-$ инвентарный номер).

Таблица 3

\section{Размеры и указатели черепов компонентов, выделенных в мужской части выборки из могильника Кикки-Акки}

\begin{tabular}{|c|c|c|c|c|}
\hline \multirow{2}{*}{$\begin{array}{c}\text { Признаки, их номера по Мартину } \\
\text { или условные обозначения }\end{array}$} & \multicolumn{2}{|c|}{1 компонент } & \multicolumn{2}{|c|}{2 компонент } \\
\hline & $x$ & $n$ & $x$ & $n$ \\
\hline 1. Продольный диаметр & 178,5 & 8 & 181,8 & 5 \\
\hline 8. Поперечный диаметр & 140,5 & 8 & 139,0 & 5 \\
\hline 17. Высотный диаметр (ba-b) & 129,4 & 8 & 128,6 & 5 \\
\hline 8:1. Черепной указатель & 78,6 & 8 & 76,4 & 5 \\
\hline 5. Длина основания черепа & 99,2 & 8 & 95,2 & 5 \\
\hline 9. Наименьшая ширина лба & 93,4 & 8 & 90,4 & 5 \\
\hline$\angle$ пил. Угол поперечного изгиба лба & 138,8 & 8 & 139,6 & 5 \\
\hline 32. Угол профиля лба от $n$. & 76,9 & 8 & 80,7 & 4 \\
\hline 40. Длина основания лица & 95,2 & 8 & 96,8 & 5 \\
\hline 45. Скуловой диаметр & 134,4 & 8 & 131,0 & 5 \\
\hline 48. Верхняя высота лица & 71,0 & 8 & 68,4 & 5 \\
\hline 72. Общий лицевой угол & 86,0 & 8 & 84,7 & 4 \\
\hline 77. Назомалярный угол & 142,0 & 8 & 147,6 & 5 \\
\hline$\angle \mathrm{zm}$. Зигомаксиллярный угол & 130,6 & 8 & 133,0 & 2 \\
\hline 51. Ширина орбиты от $m f$. & 42,8 & 8 & 41,2 & 5 \\
\hline 52. Высота орбиты & 35,1 & 8 & 33,4 & 5 \\
\hline 55. Высота носа & 52,4 & 8 & 51,2 & 5 \\
\hline 54. Ширина носа & 24,8 & 8 & 26,0 & 5 \\
\hline 75(1). Угол выступания носа & 18,6 & 8 & 15,2 & 5 \\
\hline SC. Симотическая ширина & 6,4 & 8 & 6,7 & 5 \\
\hline SS. Симотическая высота & 2,4 & 8 & 2,6 & 5 \\
\hline$\angle \mathrm{S}$. Симотический угол & 103,2 & 8 & 107,2 & 5 \\
\hline DC. Дакриальная ширина & 20,9 & 8 & 21,6 & 5 \\
\hline DS. Дакриальная высота & 9,8 & 8 & 10,1 & 5 \\
\hline СD. Дакриальный угол & 96,2 & 8 & 94,2 & 5 \\
\hline УЛС & 68,0 & - & 85,4 & - \\
\hline ПФЦ & 93,4 & - & 94,3 & - \\
\hline УДМЭ & 68,5 & - & 92,9 & - \\
\hline
\end{tabular}

Черепа дифференцировались по форме мозговой капсулы, высоте и степени уплощенности лицевого скелета, высоте орбиты и ширине носа. По степени внутреннего морфологического сходства в анализируемой совокупности было выделено две группы (рис. 1). В первую попали мезокранные черепа (табл. 3) со средне профилированным средневысоким лицом (8 индивидов), во вторую - субдолихокранные с уплощенным низким лицом (5 индивидов). Судя по особенностям строения черепной коробки, обе группы занимают промежуточное положение между европеоидными и монголоидными вариантами. Однако по степени уплощенности лицевого скелета вторая группа находится в границах изменчивости классических монголоидов. В 


\section{О.Е. Пошехонова}

результате условная доля монголоидного элемента первого компонента составила 68,5 \%, а второго - 92,9 \% (табл. 3).

\section{Обсуждение результатов}

Для выяснения сходства верхнетазовских селькупов и морфотипов, выделяемых в их составе, с той или иной близкой к современности группой населения Западной Сибири проведен межгрупповой сравнительный анализ [Дебец, 1951; Гохман, 1982; Дремов, 1998a, 1998b; Дремов, Багашев, 1998; Багашев, 1998, 2001, 2002, 2017; Багашев, Слепченко, 2015; Ким, 1998] с помощью канонического анализа. Первый канонический вектор (27,2 \% изменчивости) разделил мужские выборки по высоте черепа и лица, второй (13,9 \% изменчивости) - по ширине черепа, ширине носа, степени уплощенности лицевого скелета на верхнем уровне и углу выступания носовых костей (табл. 4). Женские группы дифференцировались по фрорме мозговой капсулы, размерам лицевого скелета, высоте грушевидного отверстия и переносья, углу выступания носовых костей и степени профилировки лица. По первому каноническому вектору $(26,4$ \% изменчивости) максимальные нагрузки приходятся на серии с более низким лицом и высоким переносьем, по второму (16,8 \% изменчивости) - на группы с более коротким и широким черепом, широким и уплощенным лицом с более выступающим носом.

Таблица 4

Величины факторных нагрузок

\begin{tabular}{|c|c|c|c|c|}
\hline \multirow{2}{*}{ Номер признака по Мартину } & \multicolumn{2}{|c|}{ 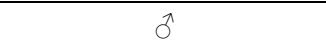 } & \multicolumn{2}{|c|}{ q } \\
\hline & I к. в. & II к. в. & І к. в. & II к. в. \\
\hline 1. Продольный диаметр & $-0,1826$ & $-0,0887$ & $-0,1162$ & $-0,3560$ \\
\hline 8. Поперечный диаметр & 0,0700 & 0,6824 & $-0,1040$ & 0,3787 \\
\hline 17. Высотный диаметр & 0,6106 & $-0,0968$ & 0,4791 & 0,2884 \\
\hline 45. Скуловой диаметр & 0,0495 & 0,0685 & $-0,2432$ & 0,3967 \\
\hline 48. Верхняя высота лица & $-0,3268$ & 0,3215 & $-0,4238$ & $-0,1013$ \\
\hline 51. Ширина орбиты от $m f$. & 0,3257 & 0,2939 & 0,2807 & 0,0534 \\
\hline 52. Высота орбиты & $-0,3353$ & $-0,1298$ & $-0,2973$ & 0,1390 \\
\hline 54. Ширина носа & 0,0916 & $-0,3169$ & 0,1398 & $-0,0557$ \\
\hline 55. Высота носа & $-0,1125$ & $-0,2482$ & $-0,1194$ & 0,4560 \\
\hline SS. Симотическая высота & 0,2246 & 0,0417 & 0,3811 & 0,1896 \\
\hline DC. Дакриальная ширина & 0,2205 & 0,0608 & 0,1615 & 0,1309 \\
\hline DS. Дакриальная высота & 0,2929 & 0,0217 & 0,2965 & $-0,0607$ \\
\hline 75(1). Угол выступания носа & $-0,2198$ & 0,3054 & $-0,1476$ & 0,2148 \\
\hline 77. Назомалярный угол & $-0,0090$ & 0,2108 & $-0,1211$ & 0,3762 \\
\hline$\angle z m^{\prime}$. Зигомаксиллярный угол & 0,0825 & $-0,0169$ & 0,1035 & 0,0372 \\
\hline Собственное значение & 15,9361 & 8,1449 & 12,6020 & 8,0035 \\
\hline Доля изменчивости, \% & 27,2 & 13,9 & 26,4 & 16,8 \\
\hline
\end{tabular}

Мужские и женские серии на построенных графиках локализовались примерно одинаковым образом, демонстрируя сходные закономерности межгрупповой изменчивости (рис. 2, 3). Выборки, относящиеся к обь-иртышскому (нарымские селькупы, томско-чулымские и тоболо-барабинские татары) [Багашев, 2017, с. 350-351] антропологическому типу западно-сибирской группы популяций, дифференцировались первым каноническим вектором и расположились компактными скоплениями в правой стороне графра. В изучаемой совокупности для них характерны наиболее высокий и более брахикранный череп, низкое лицо, широкая орбита и крупное переносье. Мужские выборки обских угров (северные манси, восточные и северные ханты), которые относятся к уральскому антропологическому типу той же формации [Там же, с. 352-353], приняв на себя значительную долю изменчивости, локализовались рассеянным скоплением в левом поле графа. Им присущи более низкий и наиболее долихокранный череп, грацильное переносье и малый угол выступания носовых костей. Женские серии, относящиеся к данному типу, из северной и южной части ареала их обитания значительно дистанцировались друг от друга. Северные ханты, имея значительную долю примеси ненецкого происхождения, обладают схожими с ненецкими физическими характеристиками. Женские группы восточных хантов отделились от всех остальных выборок по признакам второго канонического вектора. Среди исследуемых серий они обладают самым долихокранным черепом, узким профилированным лицом и меньшим углом выступания носовых костей. 


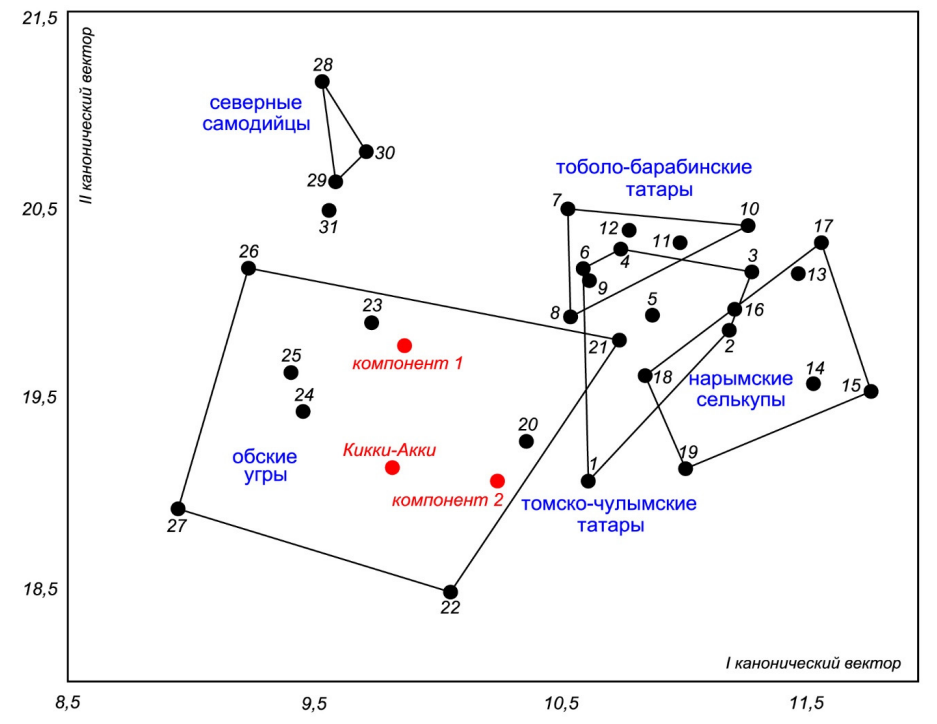

Рис. 2. Расположение близких к современности мужских выборок из Западной Сибири в пространстве I и II канонических векторов. Очерчены различные этнолингвистические группы коренного населения Западной Сибири:

1 - чулымцы, Ясашная Гора; 2 - томские татары, Козюлинский; 3 - чулымцы, рр. Яя и Кия; 4 - чулымцы, Тургай, Балагачевский; 5 - томские татары, р. Обь; 6 - томские татары, Тоянов городок [Дремов, 1998а]; 7 - аялынская группа тоболо-иртышских татар [Багашев, 1998]; 8 - барабинские татары, Кыштовка [Ким, 1998]; 9 - тобольская группа тоболо-иртышских татар; 10 - саргатская группа тоболо-иртышских татар [Багашев, 1998]; 11 - барабинские татары, Абрамове [Ким, 1998]; 12 - тюменская группа тоболо-иртышских татар [Багашев, 1998]; 13 - нарымские селькупы, Тискинский, средняя группа; 14 - нарымские селькупы, Тискинский, поздняя группа [Багашев, 2001]; 15 - нарымские селькупы, Мигалка [Багашев, 2017]; 16 - нарымские селькупы, р. Нарым [Дремов, 1998b]; 17 - нарымские селькупы,

р. Кеть [Багашев, 2002]; 18 - нарымские селькупы, р. Тым [Багашев, 2017]; 19 - нарымские селькупы, р. Чулым [Дремов, 1998б]; 20 - восточные ханты, р. Балык; 21 - восточные ханты, р. Васюган; 22 - восточные ханты, р. Салым; 23 - восточные ханты, р. Вах; 24 - восточные ханты, р. Юган; 25 - северные ханты, Обдорск [Дремов, Багашев, 1998]; 26 - северные ханты, Халас-Погор; 27 - манси северные; 28 - ненцы тундровые [Дебец, 1951]; 29 - ненцы,

р. Таз [Багашев, Слепченко, 2015]; 30 - северные самодийцы, сборная [Багашев, 2017]; 31 - кеты [Гохман, 1982].

Группы северных самодийцев, которые представлены сборными сериями черепов тундровых ненцев [Дебец, 1951], ненцев р. Таз (р. Вэсакояха и оз. Нямбойто) [Багашев, Слепченко, 2015], лесных ненцев, ненцев Яр-Сале, р. Щучья и нганасан [Bagashev, Slepchenko, в печати], плотно сгруппировались в левой верхней части графика. Для них характерны наиболее широкий череп, крупное плоское лицо, узкое грушевидное отверстие и больший угол выступания носовых костей в данной совокупности серий. Вместе с кетской выборкой, которая локализовалась очень близко к северным самодийцам, они относятся к ямало-енисейскому антропологическому типу западно-сибирской формации [Багашев, 2017, с. 354-355].

Мужская выборка из могильника Кикки-Акки расположилась в границах изменчивости обских угров между сериями восточных хантов с рек Вах, Салым, Юган и Балык, значительно отдалившись от нарымских селькупов. В основном сближают их признаки, имеющие максимальные нагрузки по первому каноническому вектору (форма и высота черепа, высота лица). Кроме этого сходство верхнетазовской серии с группами восточных хантов обусловлено дифференцирующими признаками второго канонического вектора: угол выступания носа, степень уплощенности лица и ширина грушевидного отверстия. Зафиксированное антропологическое отличие мужской части популяции верхнетазовских селькупов от нарымских селькупов и близость к восточным хантам не совпадают с этнолингвистическими градациями коренного населения Западной Сибири. В соответствии с ними и северные и нарымские селькупы относятся к одному этносу и говорят на разных диалектах одного языка [Пелих, 1981, с. 8-74; Казакевич, Будянская, 2010 , с. 3]. На культурную близость верхнетазовских и нарымских селькупов, кроме этого, уверенно указывают археологические материалы [Пошехонова, 2015b]. 


\section{О.Е. Пошехонова}

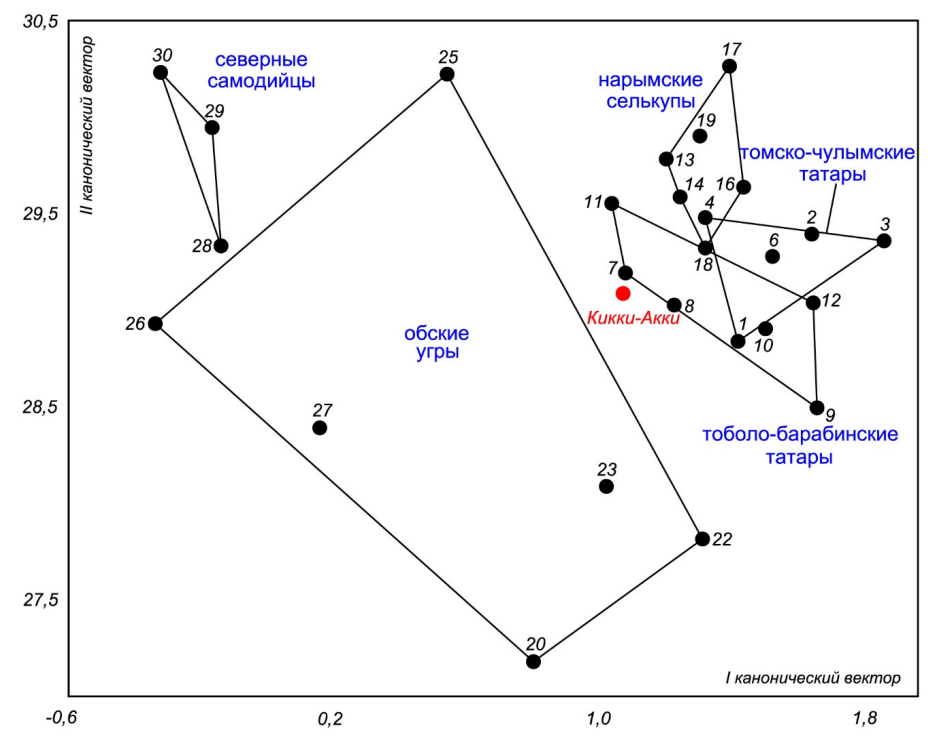

Рис. 3. Расположение близких к современности женских выборок из Западной Сибири в пространстве I и II канонических векторов (номера групп см. в подписи к рис. 2).

Очерчены различные этнолингвистические группы коренного населения Западной Сибири.

В этой связи интересно положение на графрике компонентов, выделенных в составе мужской группы из могильника Кикки-Акки. Первый морфологический тип, черепа которого характеризуются мезокраннией, средне профилированным средневысоким лицом, приближен к ваховским хантам. Второй компонент, которому свойственны субдолихокранные черепа с уплощенным низким лицом, тяготеет к хантам р. Балк. Известно, что антропологическое своеобразие этой выборки обусловлено метисационными процессами [Багашев, 2017, с. 352]. Но кроме этого, судя по локализации, второй компонент тяготеет к группам обь-иртышского антропологического типа, в том числе к нарымским селькупам. Вероятно, формирование фризических особенностей верхнетазовских селькупов происходило при активном смешении их предковой селькупской группы (компонент 2) с хантами р. Вах (компонент 1), через ареал проживания которых происходила миграция. Однако с течением времени южно-самодийский компонент был полностью ассимилирован. Расположение небольшой по численности женской серии из могильника Кикки-Акки на графрике подтверждает высказанное предположение: она локализовалась между нарымскими селькупами и хантыйской выборкой с р. Вах, с тяготением к первым, демонстрируя сходство и с теми и с другими. В отличие от мужской верхнетазовской выборки, в женской части серии эти два компонента фриксируются в относительно равных долях.

\section{Выводы}

Таким образом, установлено, что нарымские селькупы действительно являются предками верхнетазовских селькупов, но в результате миграции на север, за небольшой промежуток времени (200-300 лет), их генофонд и контролируемый им физический облик довольно сильно изменились. Мужское население верховьев р. Таз в XVIII-XIX вв. по своему антропологическому типу максимально приблизилось к восточным хантам. Однако в их антропологической структуре удалось зафиксировать присутствие морфотипа, связанного в генезисе с нарымскими селькупами. Формирование антропологического своеобразия верхнетазовских селькупов протекало при активной метисации этих двух компонентов, относящихся к одной западно-сибирской формации. Но, судя по всему, к XVIII-XIX вв. биологические связи северныX селькупов с предковой южной группой сильно ослабли и угорский компонент становится доминирующим. Для женской части верхнетазовского населения зафиксирована несколько иная ситуация. У них отчетливо фиксируются оба базовых компонента с небольшим преобладанием южно-самодийского. Увеличение численности наблюдений по женским черепам, возможно, позволит скорректировать данное заключение. 
Алексеев В.П., Дебец Г.Ф. Краниометрия: Методика антропологических исследований. М., 1964. 127 с. Багашев А.Н. Хронологическая изменчивость краниологического типа нарымских селькупов (по материалам могильника Тискино) // Вестник археологии, антропологии и этнографрии. 2001. Вып. 3. С. 159-174.

Багашев А.Н. Антропологический состав населения Прикетья (Лукьяновский и Максимоярский могильники) // Проблемы взаимодействия человека и природной среды. Тюмень: Изд-во ИПОС СО РАН, 2002. Вып. 3. С. 40-43.

Багашев А.Н. Антропология Западной Сибири. Новосибирск: Наука. 2017. 408 с.

Багашев А.Н., Слепченко С.М. Материалы по краниологии тазовских ненцев // Человек и Север: Антропология, археология, экология: Материалы всерос. конф. Тюмень: Изд-во ИПОС СО РАН, 2015. С. 6-10.

Гохман И.И. Угол поперечного изгиба лба и его значение для расовой диагностики // Вопросы антропологии. № 8. 1961. С. 88-98.

Гохман И.И. Происхождение центральноазиатской расы в свете новых антропологических материалов // СМАЭ. 1980. Т. 36. С. 5-34.

Гохман И.И. Антропологические аспекты кетской проблемы: Результаты антропологических и краниологических исследований // Кетский сборник. Л.: Наука, 1982. С. 9-42.

Дебец Г.Ф. Антропологические исследования в Камчатской области // ТИЭ. М.; Л.: Изд-во АН СССР, 1951. Т. 17. 264 C.

Дебец Г.Ф. Опыт краниометрического определения доли монголоидного компонента в смешанных группах населения СССР // Проблемы антропологии и исторической этнографии Азии. М.: Наука, 1968. С. 13-22.

Дремов В.А. Томские и чулымские тюрки // Очерки культурогенеза народов Западной Сибири. Томск: Изд-во ТГУ, 1998а. Т. 4: Расогенез коренного населения. С. 67-84.

Дремов В.А. Нарымские селькупы // Там же. 1998b. Т. 4: Расогенез коренного населения. С. 110-111.

Дремов В.А., Багашев А.Н. Ханты Среднего Приобья и Прииртышья // Там же. 1998. Т. 4: Расогенез коренного населения. С. 111-124.

Казакевич О.А., Будянская Е.М. Предисловие // Диалектологический словарь селькупского языка: (Северное наречие) / Под ред. О.А. Казакевич. Екатеринбург: Баско, 2010. С. 3-4.

Ким А.Р. Барабинские татары // Очерки культурогенеза народов Западной Сибири. Томск: Изд-во ТГУ, 1998. Т. 4: Расогенез коренного населения. С. 84-94. $176 \mathrm{c}$.

Пелих Г.И. Селькупы XVII в.: Очерки социально-экономической истории. Новосибирск: Наука, 1981.

Пошехонова О.Е. Краниология верхнетазовских селькупов // Человек и Север: Антропология, археология, экология: Материалы всерос. конф. Тюмень: Изд-во ИПОС СО РАН, 2015а. С. 46-52.

Пошехонова О.Е. Новые данные о верхнетазовских селькупах XVII-XIX веков // IV Сев. археол. конгресс: Материалы. Екатеринбург, 2015b. С. 200-202.

\section{O.E. Poshekhonova}

Tyumen Scientific Centre of Siberian Branch RAS Malygina st., 86, Tyumen, 625026, Russian Federation

E-mail: poshehonova.olg@gmail.com

\section{NEW DATA ON SELKUP CRANIOLOGY FROM THE UPPER TAZ RIVER BASIN}

Some researchers pointed out that the anthropological originality of some native groups of Western Siberia was formed as a result of late metisation processes that occurred in modern times. Judging by historical and ethnolinguistic data, one of such peoples is the Northern Selkups, who moved to the Upper Taz River basin in the XVII century for political, economic and, possibly, environmental reasons. Paleoontropological data can be an important source for solving the issue of their origin. The article is dedicated to the analysis of the craniological collection from Kikki-Akki burial, received in 2013 and replenished in 2016. The cranial characteristic of this group is reduced to a combination of the following features: a low subdolichocranial skull, a slightly flattened mediumwide and medium-high mesoprozopic face, a flat nose and a very small nasal protrusion angle. The intra-group variability of the male part of the series was studied. In terms of the degree of internal morphological similarity, two groups were singled out in the population under consideration. The first were mesocranial skulls with a moderate protrusion medium-high face (8 individuals), the second were subdolichocranial skulls with a flattened low face (5 individuals). It has been established that the Selkups from the Narym River area are indeed the ancestors of the Selkups from the Upper Taz River region, but their physical appearance changed over a short period of time (200-300 years) because of migration to the north. According to its anthropological type, male population of the Upper Taz River region in the XVIII-XIX centuries became as close as possible to the Eastern Khanty. However, it was possible to find in their anthropological structure features of the morphotype associated in genesis with the Selkups from the Narym River region. Formation of the anthropological originality of the Selkups from the Upper Taz River region proceeded with an active metisation of these two components belonging to one West 


\section{О.Е. Пошехонова}

Siberian formation. However, biological connections of the Northern Selkups with the ancestral group from the Narym River region apparently weakened by the XVIII-XIX centuries, and the Ugric component became dominant. A different situation is observed in the female population from the Upper Taz River region. They clearly have both basic components, with a slight predominance of the Southern Samoyedic.

Key words: Western Siberia, Late Middle Ages, Northern Selkup, paleoanthropology, anthropological type, craniology.

DOI: $10.20874 / 2071-0437-2018-41-2-109-118$

\section{REFERENCES}

Alekseev V.P. Debets G.F., 1964. Kraniometriia: Metodika antropologicheskikh issledovanii [Craniometry: Methodology of anthropological research], Moscow, $127 \mathrm{p}$.

Bagashev A.N., 2001. Hronologicheskaja izmenchivost' kraniologicheskogo tipa narymskih sel'kupov (po materialam mogil'nika Tiskino) [Chronological variability of Narym Selkup craniological type (based on Tiskino)]. Vestnik arheologii, antropologii i jetnografii, 3, pp. 159-174.

Bagashev A.N., 2002. Antropologicheskii sostav naseleniia Priket'ia (Luk'ianovskii i Maksimoiarskii mogil'niki) [The anthropological structure of the Ket River population (Lukyanovsky and Maksimoyarsky burial grounds)]. Problemy vzaimodeistviia cheloveka i prirodnoi sredy, 3, Tiumen', pp. 40-43.

Bagashev A.N., Slepchenko S.M., 2015. Materialy po kraniologii tazovskikh nentsev [Craniological materials of the Taz Nenets]. Chelovek i Sever: Antropologiia, arkheologiia, ekologiia: Materialy vserossiiskoi konferentsii, Tiumen', pp. 6-10. $408 \mathrm{p}$.

Bagashev A.N., 2017. Antropologiia Zapadnoi Sibiri [Anthropology of Western Siberia], Novosibirsk: Nauka,

Debets G.F., 1951. Antropologicheskie issledovaniia v Kamchatskoi oblasti [Anthropological studies in Kamchatka Region]. Trudy Instituta etnografii, vol. 17, 264 p.

Debets G.F., 1968. Opyt kraniometricheskogo opredeleniia doli mongoloidnogo komponenta v smeshannykh gruppakh naseleniia SSSR [An attempt of craniometric determination of the proportion of the Mongoloid component in the mixed population groups of the USSR]. Problemy antropologii $i$ istoricheskoi etnografii Azii, Moscow: Nauka, pp. 13-22.

Dremov V.A., 1998a. Tomskie i chulymskie tiurki [Tomsk and Chulym Turks]. Ocherki kul'turogeneza narodov Zapadnoi Sibiri, vol. 4, Tomsk: Izdatelstvo TGU, pp. 67-84.

Dremov V.A., 1998b. Narymskie sel'kupy [Selkup people in Narym region]. Ocherki kul'turogeneza narodov Zapadnoi Sibiri, vol. 4, Tomsk: Izdatelstvo TGU, pp. 110-111.

Dremov V.A., Bagashev A.N., 1998. Khanty Srednego Priob'ia i Priirtysh'ia [Khanty of the Middle Ob and the Irtysh region]. Ocherki kul'turogeneza narodov Zapadnoi Sibiri, vol. 4, Tomsk: Izdatelstvo TGU, pp. 111-124.

Gokhman I.I., 1961. Ugol poperechnogo izgiba lba i ego znachenie dlia rasovoi diagnostiki [Angle of transverse bending of the forehead and its value for racial diagnosis]. Voprosy antropologii, no. 8, pp. 88-98.

Gokhman I.I., 1980. Proiskhozhdenie tsentral'noaziatskoi rasy v svete novykh antropologicheskikh materialov [The origin of the Central Asian race in the light of new anthropological materials]. Sbornik Muzeia antropologii i etnografii im. Petra Velikogo (Kunstkamery), vol. 36, pp. 5-34.

Gokhman I.I., 1982. Antropologicheskie aspekty ketskoi problemy: Rezul'taty antropologicheskikh i kraniologicheskikh issledovanii [Anthropological aspects of the Ket problem: Results of anthropometric and craniological studies]. Ketskii sbornik, Leningrad, pp. 9-42.

Kazakevich O.A., Budianskaia E.M., 2010. Predislovie [Introduction]. Dialektologicheskii slovar' sel'kupskogo iazyka: (Severnoe narechie), Ekaterinburg: Basro, pp. 3-4.

Kim A.R., 1998. Barabinskie tatary [The Baraba Tatars]. Ocherki kul'turogeneza narodov Zapadnoi Sibiri, vol. 4, Tomsk: Izdatelstvo TGU, pp. 84-94.

Pelikh G.I., 1981. Sel'kupy XVII v.: Ocherki sotsial'no-ekonomicheskoi istorii [Selkups of the $17^{\text {th }}$ century: Essays on socio-economic history], Novosibirsk: Nauka, 176 p.

Poshekhonova O.E., 2015a. Kraniologiia verkhnetazovskikh sel'kupov [Craniology of the Selkup people in Upper Taz River region]. Chelovek i Sever: Antropologiia, arkheologiia, ekologiia: Materialy vserossiiskoi konferentsii, Tiumen', pp. 46-52.

Poshekhonova O.E., 2015b. Novye dannye o verkhnetazovskikh sel'kupakh XVII-XIX vekov [New data on the Selkups of the $17^{\text {th }}-19^{\text {th }}$ centuries in the Upper Taz River region]. IV Severnyi arkheologicheskii kongress: Materialy, Ekaterinburg, pp. 200-202. 